\title{
Annual Report: Property Improvement in CZT via Modeling and Processing Innovations
}

$\mathrm{CH}$ Henager, Jr. (PI)

Wahyu Setyawan

Fei Gao

Shenyang $\mathrm{Hu}$

Mary Bliss

Brian Riley

Kyle Alvine

Jean Stave

September 2013

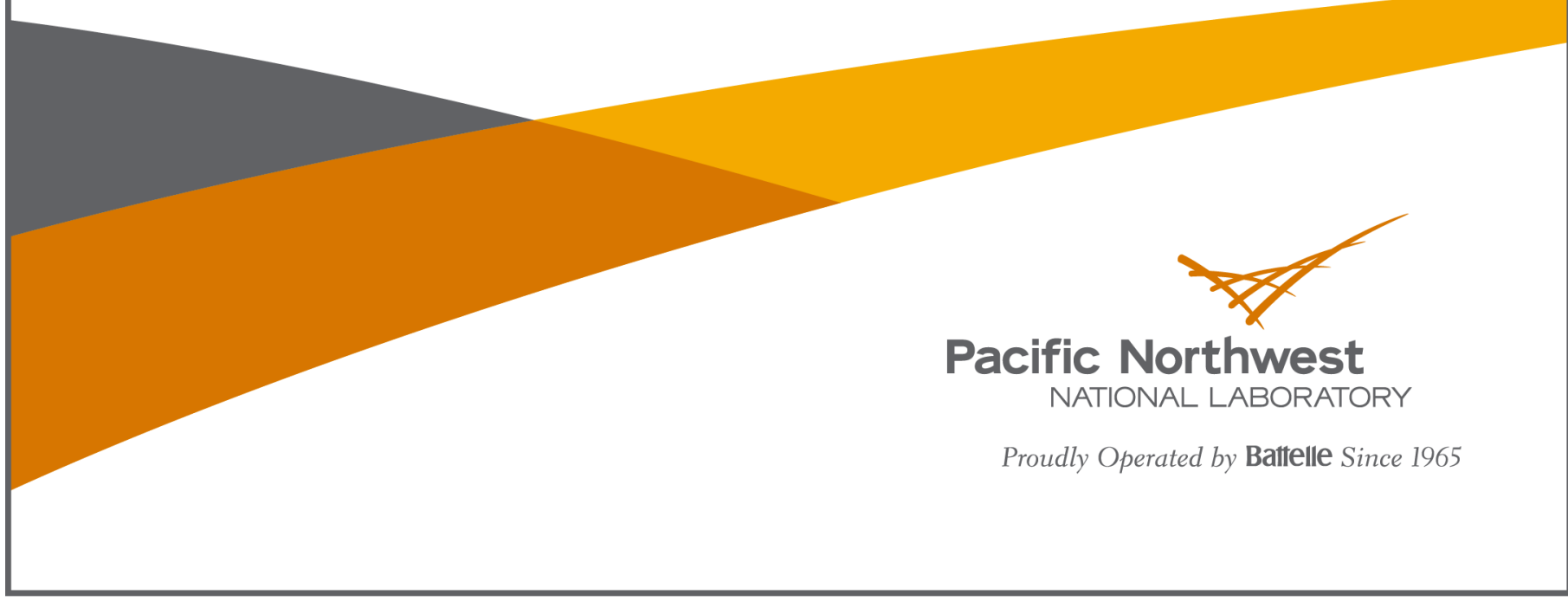




\title{
DISCLAIMER
}

This report was prepared as an account of work sponsored by an agency of the United States Government. Neither the United States Government nor any agency thereof, nor Battelle Memorial Institute, nor any of their employees, makes any warranty, express or implied, or assumes any legal liability or responsibility for the accuracy, completeness, or usefulness of any information, apparatus, product, or process disclosed, or represents that its use would not inf ringe privately owned rights. Reference herein to any specific commercial product, process, or service by trade name, trademark, manufacturer, or otherwise does not necessarily constitute or imply its endorsement, recommendation, or favoring by the United States Government or any agency thereof, or Battelle Memorial Institute. The views and opinions of authors expressed herein do not necessarily state or reflect those of the United States Government or any agency thereof.

\author{
PACIFIC NORTHWEST NATIONAL LABORATORY \\ operated by \\ BATTELLE \\ for the \\ UNITED STATES DEPARTMENT OF ENERGY \\ under Contract DE-AC05-76RL01830
}

Printed in the United States of America
Available to DOE and DOE contractors from the
Office of Scientific and Technical Information,
P.O. Box 62, Oak Ridge, TN 37831-0062;
ph: (865) 576-8401
fax: $(865) 576-5728$
email: reports $(\boldsymbol{a})$ donis.osti.gov

Available to the public from the National Technical Information Service

5301 Shawnee Rd., Alexandria, VA 22312

ph: (800) 553-NTIS (6847)

email: orders@ntis.gov $<$ http://www.ntis.gov/about/form.aspx $>$

Online ordering: http://www.ntis.gov

This document was printed on recycled paper. 


\begin{abstract}
Annual Report
Property Improvement in CZT via Modeling and Processing Innovations
\end{abstract} PL10-CZTproc-PD05

Lab:

Project PI:

Primary Author:

Contributors:

Date:
Pacific Northwest National Laboratory (PNNL)

Chuck Henager, Jr.,

Chuck Henager, Jr.

Wahyu Setyawan, Fei Gao, Shenyang Hu, Mary Bliss, Brian Riley, Kyle Alvine, and Jean Stave

September 24, 2013 


\title{
Property Improvement in CZT via Modeling and Processing Innovations
}

\author{
PL10-CZTproc-PD05
}

\section{AIM AND SIGNIFICANCE}

The objective of this project is to develop growth models of CZT crystals from the melt using vertical gradient freeze (VGF) as a typical process. Further, the project will perform critical experiments to validate growth models and to provide detailed data for modeling and simulation. Ideally, the project will develop growth models that will provide, for the first time, choices for optimal CZT single crystal growth from the melt based on model input. In our view this depends on 1) understanding crystal growth processes, including annealing and cool-down processing, and 2) understanding the role of defects on detector response since it is not possible, yet, to produce defect-free materials. Models of defect structure and formation are addressed. Validated models and experiments on reducing defects in melt-grown crystals are used to guide our understanding of growth processes and in-furnace annealing plus cooldown.

This work has demonstrated that CZT growth occurs naturally along the $<110>$-direction, which results in facetted growth fronts, higher Te-particle content, and higher dislocation density. Since dislocations appear to seed Te-particle nucleation and growth this is not optimal. Rather, we find that $<111>$-direction appears to be the optimal growth direction resulting in lower Te-particle content and reduced dislocation densities, but that this growth direction requires seeded growth.

\section{TECHNICAL APPROACH}

We created a multiscale-modeling framework for simulations of CZT growth from the melt and validated these models using data from a VGF growth of CZT at PNNL and from a variety of CdTe laboratoryscale growths. The multiscale approach ultimately ran into issues at the atomistic-scale with an inability to create an accurate interatomic potential for CdTe or CZT. However, valuable information has been generated by this project using molecular dynamics of solidification that impact CZT growth choices. Other modeling tools were developed at the mesoscale level that were more successful in linking theory to experiment using phase field methods and experimental data.

This project made good use of new and modern characterization methods to quantify Te-particle orientations in CZT, to study the size and spatial distributions of Te-particles in CZT, and to study the growth of CdTe from the melt. Electron backscatter diffraction (EBSD) and transmitted IR (TIR) imaging with 3D mapping tools provided us with new and important data for CZT melt growth physics. Growths of Te-rich CdTe as a function of cooling rates in laboratoryscale growths revealed some important growth mechanisms for the first time.

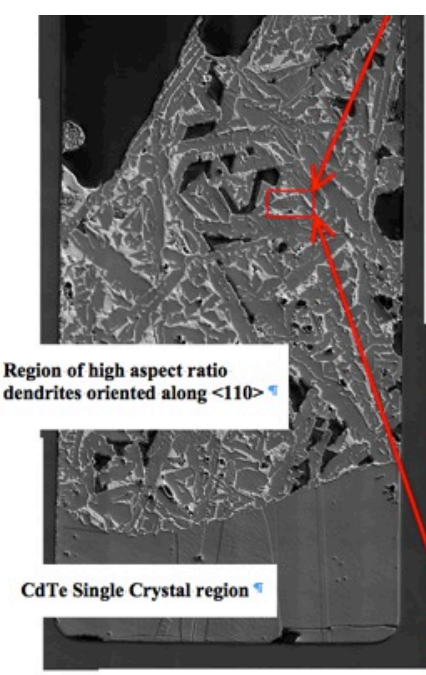

(a)

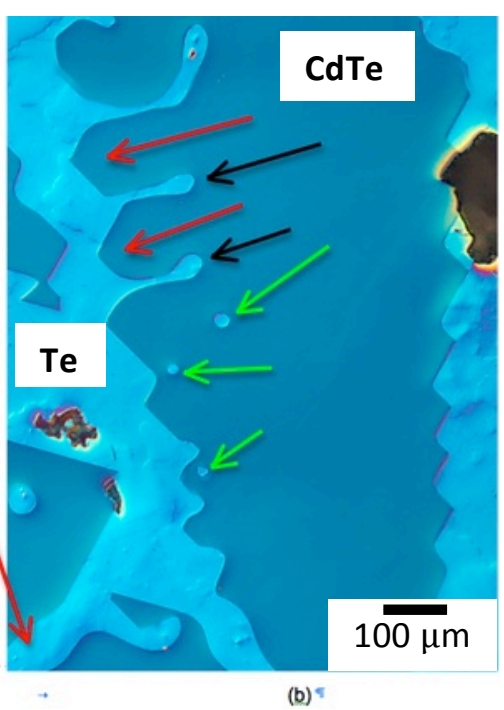

Figure 1. CdTe laboratory-scale growth. In (a) is entire freeze with $<110>$ dendrites. In (b) is high resolution image showing characteristic $<110>$ growth fingers and Te-particle capture.

\section{SCIENTIFIC FINDINGS}

We developed a phase field model describing the diffusional growth and crystallography of large Teparticles in CZT. We found that the particles occupy a (111)-tetrahedron within the CZT crystal with the 
(111) surface energy of the CZT determining the minimum energy morphology at equilibrium. Molecular dynamics (MD) results (see Figure 2) reveal that a (111) growth interface is preferred for smooth interfaces and low defect densities. However, since the $\langle 110>$ or $\langle 112>$ growth direction is self-selected by CZT this will require (111) seeded growth to achieve.

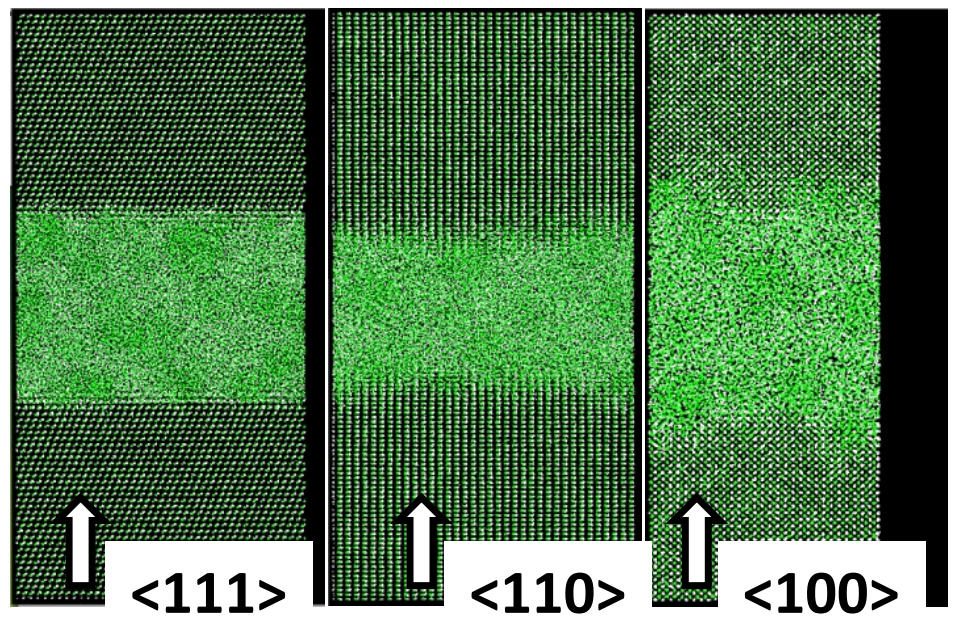

(a)

(b)

(c)

Figure 2. Atomic models using PNNL-developed potential for CdTe showing (a) $<111>$, (b) $<110>$, and (c) $<100>$ growth directions. The $<110>$ direction is fastest growing and self-selected but is rough as is the $<100>$ growth interface. In contrast the $<111>$ is slower via a ledge growth mechanism and is much smoother leading to lower defect densities. This can only be chosen via seeded growth, however.

Our most important finding may be the experimental work that we have done using TIR imaging and 3D particle mapping to determine the Te-particle size and spatial distributions within an as-grown CZT boule. The boule slice is shown in Figure 3 and the spatial distribution of Te-particles from a large volume within the boule slice is shown in Figure 4. The key result is the Te-particles form a network that greatly resembles a dislocation cellular network implying that the Te-particles in CZT may indeed coexist with dislocations. This is significant in helping determine optimal growth strategies.

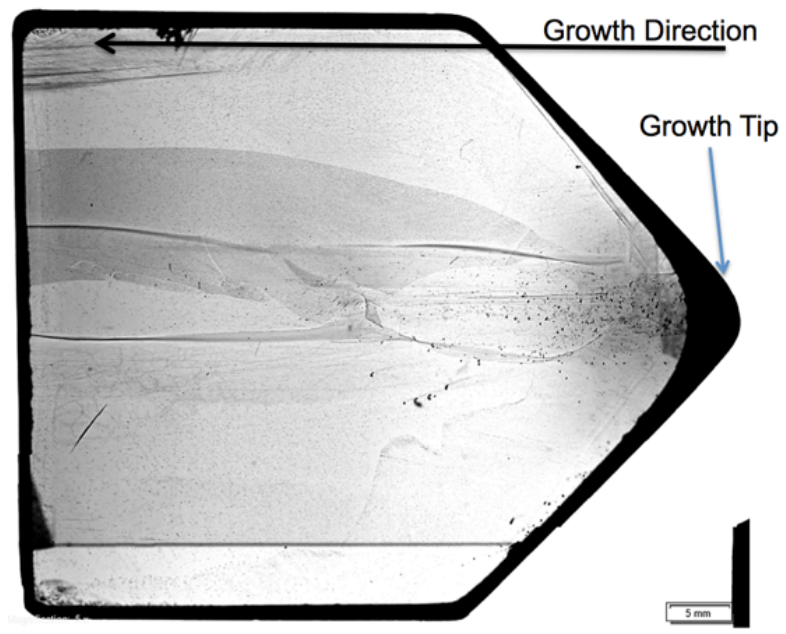

Figure 4. Transmitted IR image of CZT boule slice grown at PNNL. Speckles in the image are Te-particles. 


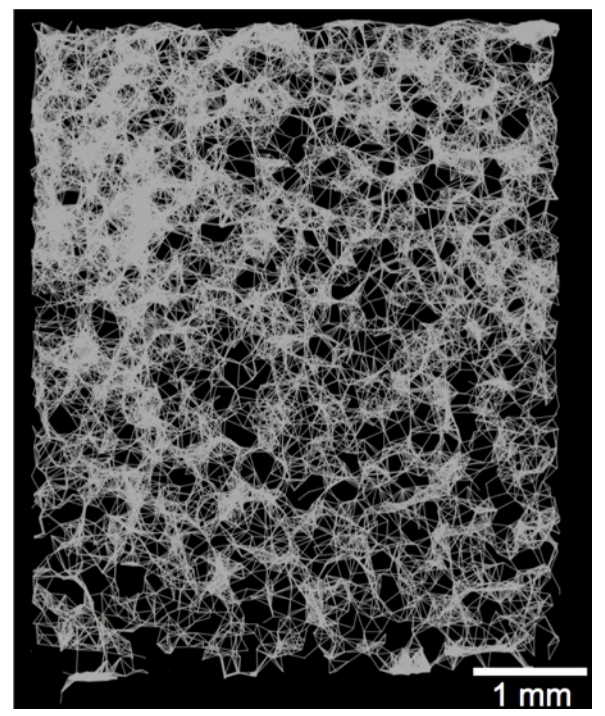

Figure 5. Cellular network model of Te-particles in CZT from Fig. 4. Stick bonds up to $175 \mu \mathrm{m}$ long connect the Teparticles. The cell size is about $150 \mu \mathrm{m}$, which corresponds to the dislocation network size in CZT.

\section{PATH FORWARD}

This research has identified a need for determining the effects of as-grown CZT microstructures and Teparticle distributions on energy loss and energy resolution. Currently, there is no adequate theory of energy resolution degradation for semiconductor radiation detectors with as-grown defects. We recommend such a study, since without such a theory it is difficult to envision improved crystal growth models or optimal growth process developments.

\section{PUBLICATIONS AND INVITED PRESENTATIONS}

CH Henager, Jr., DJ Edwards, AL Schemer-Kohrn, SK Sundaram, BJ Riley, and M Bliss, "Electron Backscatter Diffraction of a Ge Growth Tip from a VGF Furnace", J. Cryst. Growth (2008) 311(1):10-14.

SY Hu and CH Henager, Jr., "Phase-field Simulations of Te-Precipitate Morphology and Evolution Kinetics in Te-Rich CdTe Crystals", J. Cryst. Growth (2009) 311(11):3184-3194.

CH Henager, Jr., DJ Edwards, AL Schemer-Kohrn, M Bliss, and JE Jaffe, "Preferential orientation of Te precipitates in melt-grown CZT", J. Cryst. Growth (2009) 311(9):2641-2647.

$\mathrm{CH}$ Henager, Jr. and JR Morris, "Atomistic simulation of CdTe solid-liquid coexistence equilibria", Physical Review B (2009) 80(24):Article Number: 245309.

SK Sundaram, CH Henager, Jr., DJ Edwards, AL Schemer-Kohrn, M Bliss, and BJ Riley, "EBSD Analysis of a CZT Growth Tip from a VGF Furnace", J. Cryst. Growth (2011) 329(1):12-19.

SY Hu, CH Henager, Jr., and LQ Chen, "Simulations of Stress-induced Twinning and De-twinning: a Phase-field Model", Acta Materialia (2010) 58(19):6554-6564.

G Lin, J Bao, AM Tartakovsky, and CH Henager, Jr., "A phase-field model coupled with lattice kinetics solver for modeling crystal growth in furnaces", Commun. Comput. Phys. (2012) 15 (2014), pp. 76-92.

CH Henager, Jr., "Crystal Growth Modeling: Atoms to Continuum", Presented by Chuck Henager, Jr. (Invited Speaker) at NA-22 Theory and Modeling Workshop, Berkeley, CA on October 30, 2008.

CH Henager, Jr., and JR Morris, "CdTe-interfaces", Presented by James R Morris (Invited Speaker) at CMSN workshop, San Francisco, CA on February 19, 2009.

CH Henager, Jr., "Multiscale Modeling of Crystal Growth and Microstructural Evolution of CdZnTe", Presented by Chuck Henager, Jr. (Invited Speaker) at APS March Meeting (American Physical Society), Baltimore, MD on March 21, 2013. 


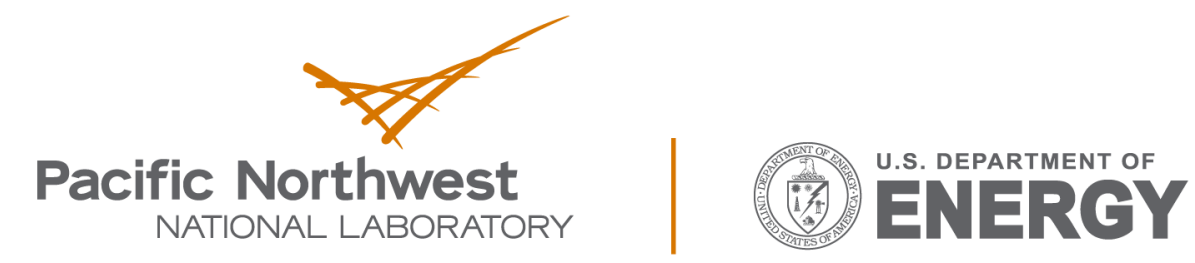

Proudly Operated by Battelle Since 1965

902 Battelle Boulevard

P.O. Box 999

Richland, WA 99352

1-888-375-PNNL (7665)

www.pnnl.gov 